INTERNATIONAL JOURNAL OF MULTIDisciplinARY RESEARCH AND ANALYSis

ISSN(print): 2643-9840, ISSN(online): 2643-9875

Volume 04 Issue 06 June 2021

DOI: 10.47191/ijmra/v4-i6-04, Impact Factor: 6.072

Page No.- 705-711

\title{
Land Evaluation, Sustainable Land Management and Impacts of Climate Change in Agriculture; Ethiopia: Review
}

Yohannes Habteyesus Yitagesu

Ethiopia Institute of Agricultural Research (Holetta Research Center)

ABSTRACT: Sustainable land management has emerged as an issue of major global concern. In many countries particularly in Ethiopia, the concern of suitable land management is because of the-increasing population pressure on limited land resources, demanding for increased food production, the degradation of land and water resources accelerating rapidly. If the lands well suited for agriculture, it will follows further increases in production to meet the food demands of increasing populations, must come about by the more intensive use of existing agricultural lands. Climate \& soil conditions, land use type and management, determine the production limit. To contest cited venomous effects of intensification, regard to environmental effects requires the development and implementation of technologies and policies, which will result in sustainable land management (Gisla-dottir and Stocking, 2005; Campbell and Hagmann, 2003).

The major factors reason for low productivity include dependence on traditional farming techniques, soil degradation caused by overgrazing and deforestation, poor corresponding services such as extension, credit, marketing, infrastructure, and climatic factors such as drought and flood (Deressa, Hassan, \& Ringler, 2011). In addition to the low soil fertility, soil degradation in Ethiopia; reduces soil productivity which results to food insecurity, economic losses and aggravates the recurrent droughts (Shiferaw \& Holden, 1999; Mitiku et al., 2006). It has also increases vulnerability of people to the adverse effects of climate variability and change, by reducing soil organic carbon level and water holding capacity, which in turn decreases agricultural productivity and local resource assets (TerrAfrica, 2009; Nyssen et. al., 2003a; Hurni, 2000; Mitiku Haile,2006 \& Daniel et al., 2015). Climate change causes wide-ranging effects on the environment, socioeconomic and associated sectors: water resources, agriculture and food security, human health, terrestrial ecosystems, and biodiversity (Belay Zerga \& Getaneh Gebeyehu, 2016).

Ethiopia is extremely vulnerable to climate related disasters including drought, heavy rains, floods, frost and heat waves which leads to a negative impacts on agriculture, food security, rural livelihoods, and economic development (NMA 2007).

Planning of changes in land use requires a inclusive knowledge of the natural resources; a trustworthy estimate of what they are capable of producing, so that reliable predictions and recommendations can be made. Production potential, the conservation of soil and water resources for use by future generations requires consideration in planning land development. For these reasons sustainable land management is now getting considerable attention from development experts, policy makers and researchers. In long-term period, any utilization over its capability of the land will cause degradation and yield reduction. Therefore, to know the land production capacity and to allocate the land to the satisfactory and to the most profitable should be cared.

KEYWORDS: Soil survey; Land evalutions; Green house gas; Sustainable Land Management

\section{INTRODUCTIONS}

Sustainable land management has emerged as an issue of major global concern. In many countries particularly in Ethiopia, the concern of suitable land management is because of the-increasing population pressure on limited land resources, demanding for increased food production, the degradation of land and water resources accelerating rapidly. If the lands well suited for agriculture, it will follows further increases in production to meet the food demands of increasing populations, must come about by the more intensive use of existing agricultural lands. Climate $\&$ soil conditions, land use type and management, determine the production limit.To contest cited venomous effects of intensification, regard to environmental effects requires the development and implementation of technologies and policies, which will result in sustainable land management (Gisla-dottir and Stocking, 2005; Campbell and Hagmann, 2003). 


\section{Land Evaluation, Sustainable Land Management and Impacts of Climate Change in Agriculture; Ethiopia: Review}

The major factors reason for low productivity include dependence on traditional farming techniques, soil degradation caused by overgrazing and deforestation, poor corresponding services such as extension, credit, marketing, infrastructure, and climatic factors such as drought and flood (Deressa, Hassan, \& Ringler, 2011). In addition to the low soil fertility, soil degradation in Ethiopia; reduces soil productivity which results to food insecurity, economic losses and aggravates the recurrent droughts (Shiferaw \& Holden, 1999; Mitiku et al., 2006). It has also increases vulnerability of people to the adverse effects of climate variability and change, by reducing soil organic carbon level and water holding capacity, which in turn decreases agricultural productivity and local resource assets (TerrAfrica, 2009; Nyssen et. al., 2003a; Hurni, 2000; Mitiku Haile,2006 \& Daniel et al., 2015). Climate change causes wide-ranging effects on the environment, socioeconomic and associated sectors: water resources, agriculture and food security, human health, terrestrial ecosystems, and biodiversity (Belay Zerga \& Getaneh Gebeyehu, 2016). Ethiopia is extremely vulnerable to climate related disasters including drought, heavy rains, floods, frost and heat waves which leads to a negative impacts on agriculture, food security, rural livelihoods, and economic development (NMA 2007).

Planning of changes in land use requires a inclusive knowledge of the natural resources; a trustworthy estimate of what they are capable of producing, so that reliable predictions and recommendations can be made. Production potential, the conservation of soil and water resources for use by future generations requires consideration in planning land development.

For these reasons sustainable land management is now getting considerable attention from development experts, policy makers and researchers.

In long-term period, any utilization over its capability of the land will cause degradation and yield reduction. Therefore, to know the land production capacity and to allocate the land to the satisfactory and to the most profitable should be cared.

\section{LAND EVALUATIONS}

land evaluation compare or-match the requirements of each potential land use with the characteristics of each kind of land. The result of land evaluations measure the suitability of each kind of land use for each kind of land (Edouard S., 1972). Land may be evaluated directly through the collection and processing of crop-yield data or indirectly (deducted from the observation) assumed that a number of diagnostic criteria influence land performance in a reasonably predictable manner (Willy $\mathrm{H}$. Verheye, 2009).

\subsection{How land is evaluated}

To evaluate land the following parameters will be applied.

\section{A. Defining objectives}

Objectives will be different at each of these levels, but the same approach is used to define objectives which in turn determine the 'best' land use for the area.The major stages are to: identify relevant types of land use; Carry out surveys to establish needs and wishes of the local land users and needs of the community as a whole; and rank objectives in order of priority

\section{B. Collecting the data, data to be needed:}

physical land resources (climate, land and water resources)

Socio-economic issues-human populations,

- land tenure, other legal issues and constraints

- development objectives and policies

Present land use

- major land uses and land use types

- vegetation types and distribution

- prevalent pests and diseases

Infrustracture

\section{Identifying land uses}

The aim is to recognize and describe land utilization types that are either in existence or that could be developed.

\section{Identifying land units}

'Land units, or land-mapping units, are areas with and qualities that differ sufficiently from those of other land units to affect their suitability for different land uses.'

\section{E. Assessing suitability}

The final assessment of suitability (a measure of how well the qualities of a land unit match the requirements of a particular form of land use) is usually based on one of three principles.

The limiting condition principle: the most unfavourable quality determines the suitability classification. The subjective assessment principle: suitability classes are raised or lowered on the basis of judgements of the importance of different factors. Because subjective assessments are risky, the relevant factors are weighted, and account is taken of special limitations that may occur if 


\section{Land Evaluation, Sustainable Land Management and Impacts of Climate Change in Agriculture; Ethiopia: Review}

two or more negative factors occur together.The principle of arithmetic modelling: the fact that each land quality has an independent influence on suitability means that land qualities can be assigned values and manipulated arithmetically to provide a numerical assessment of overall suitability.

\section{F. Identifying environmental and socio-economic issues}

Conservation interests are taken into account in the matching process, Irrigation schemes, Forestry activities, Changes in microclimate, moisture retention and run-off associated with large-scale forest felling or plantation are more difficult to assess.

\section{G. Identifying the most suitable land use}

'The best land use has to be selected in the light of economic, social, and sometimes political factors.' The requirements of types of land use or crop are compared with the characteristics and qualities of each land unit. This matching process provides a measure of how successful any land use would be on a specific land unit.

\section{H. Planning land use}

'Whilst land evaluation is focussed on the potential of individual land units for various uses,land planning must examine the relationships between uses.

Land evaluation provides practical answers to such questions as "What other uses of land are physically possible and economically and socially relevant?", "What inputs are necessary to bring about a desired level of production?", and "What are the current land uses and what are the consequences if current management practices stay the same?".

Land evaluation can be carried out at local, national regional and even global scales and with different levels of quantification. It is applicable both in areas where there is strong competition between existing land uses in highly populated zones as well as in zones that are largely undeveloped (FAO.,1976; Edouard S.,1972).

\section{Teble 1: Main conceptual steps in land-evaluation}

\begin{tabular}{|c|c|}
\hline Staps & Description \\
\hline $\begin{array}{l}\text { Step 1: Initial consultation on the } \\
\text { objectives }\end{array}$ & $\begin{array}{l}\checkmark \text { Consultation is leading up to the setting of objectives and noting of any } \\
\text { assumptions (like demography, infrastructure, land tenure, market } \\
\text { demand and prices, inputs, location, etc.) } \\
\checkmark \quad \text { Relevant land-use options defined at this stage. } \\
\checkmark \quad \text { The outcome of these consultations determines the scope and } \\
\text { intensity of surveys in order to fill data gaps. }\end{array}$ \\
\hline $\begin{array}{l}\text { Step 2: Determination of the } \\
\text { requirements of relevant land-use } \\
\text { options }\end{array}$ & $\begin{array}{l}\checkmark \text { In reconnaissance studies, the descriptions correspond to major } \\
\text { divisions of rural land use, e.g. rain-fed or irrigated agriculture, } \\
\text { grassland or forestry. However, for detailed studies, more information } \\
\text { on the management conditions is required since, in practice, these } \\
\text { strongly influence the attainable levels of production. }\end{array}$ \\
\hline Step 3: Mapping land qualities & $\begin{array}{l}\text { It is the spatial unit of analysis for evaluation of suitability, the } \\
\text { delineation of this unit should be based on land qualities. Thus, } \\
\text { depending on the objectives of the evaluation, relevant 'core' data sets } \\
\text { may include soils, landform, climate, vegetation, and surface and/or } \\
\text { groundwater reserves. }\end{array}$ \\
\hline $\begin{array}{l}\text { Step 4: Interim matching of land-use } \\
\text { requirements with actual land } \\
\text { qualities }\end{array}$ & $\begin{array}{l}\checkmark \text { suitability assessment for each land-mapping unit can be made taking } \\
\text { into consideration only the physiological requirements of a specific } \\
\text { crop(s) and the existing biophysical land conditions. These sets of } \\
\text { information allow prediction of theoretical crop performance (yields). }\end{array}$ \\
\hline Step 5: Final matching & $\begin{array}{l}\checkmark \text { The interim suitability classifications produced in the preceding step } \\
\text { may be re-evaluated taking into consideration a range of additional } \\
\text { factors } \\
\checkmark \quad \text { The potential impacts(soil erosion, salinization, pasture degradation), } \\
\text { should be assessed and subsequently considered in modifying the } \\
\text { results of the interim matching process. } \\
\checkmark \quad \text { Economic and social analyses help to identify problems in relation to } \\
\text { potential land uses. }\end{array}$ \\
\hline
\end{tabular}

Source: $(F A O, 1976)$ 


\section{Land Evaluation, Sustainable Land Management and Impacts of Climate Change in Agriculture; Ethiopia: Review}

\subsection{Land use planning in Ethiopia}

Land use Planning is the formulation of policies and programmes for the use of land, development of areas which previously were empty under natural vegetation. In Ethiopia, the policies and programmes will be concerned with areas in which several different uses for the same land are possible. Land use planning makes decisions (based on the information on physical, social and economic aspects) about which uses shall prevail on which kinds of land.

\section{SOIL SURVEY}

A soil survey describes the characteristics of the soils in a given area, classifies the soils according to a standard system of classification, plots the boundaries of the soils on a map, and makes predictions about the behavior of soils. The different uses of the soils and how the response of management affects them are considered. The information collected in a soil survey helps in the development of land-use plans and evaluates and predicts the effects of land use on the environment (soil survey, 2017).

Soil survey may give the following results:

- Investigate the geographical distribution of soils that occur in a given area;

- determine the most important characteristics of the soils;

- delineate map units and describe them in a logical legend in terms of dominant, associated and inclusion soil units, including classification of soils. Soil surveys ultimately lead to evaluation of the quality of the different map units for specific types of land use (Deckers J., 2014).

\subsection{Uses of Soil Surveys}

Soil surveys most commonly are made for areas that have more than one kind of important land use and for users who have varied interests and needs. Predictions for uses of soils other than farming, grazing, wildlife habitat and forestry have tended to concentrate on limitations of soils for the intended uses (Soilsurvey, 2017).

The information gathered in a soil survey may be used to predict the potentials and limitations of soils for many specific uses. The predictions(evaluated along with economic, social, and environmental considerations) of soil surveys serve as a basis for judgment about land use and management for both small tracts and regions of several million acres (Deckers J., 2014;Soil survey, 2017). Soil surveys are used to appraise potentials and limitations of soils in local areas having a common administrative structure. It applies to community units-villages, towns, townships, counties, parishes, and to trade areas that include more than one local political unit. The information is important in planning specific land use and the practices needed to obtain desired results.

Soil surveys provide information in terms of soil qualities that bear directly on land value for many different purposes. These interpretations are used most often, however, in assessing farmland for taxation and equalization, in appraising land for loans, and in guiding land buyers. Its commonly provide essential data and information for the compilation of general soil maps. It has also provide information for compiling soil maps for areas that are largely unsurveyed soil (Survey, 2017)

Research and studies in Ethiopia show that insecurity of land tenure restricts rights in land, reduces incentives to productively invest in land and limits transferability of land. In turn, these pose significant constraints to agricultural growth and natural resource management. The exercise analyzed land tenure security, land policy, land administration, land management, and related issues, including the transferability of land use rights and land certification programs as they impact food security and agricultural development in Ethiopia (Survey, 2017).

\section{SUSTAINABLE LAND MANAGEMENT (SLM)}

Sustainable Land Management is use of land resources such as soils, water, animals and plants for the production of goods to meet changing human needs while assuring the long-term productive potential of these resources and the maintenance of their environmental functions (Herweg et al., 1998). SLM is the foundation of sustainable agriculture and a strategic component of sustainable development and poverty reduction (Hurni and Meyer, 2002).

Strong humidity or aridity are basic limitations for sustainable land management, it is difficult to overcome unless by intensive efforts. Climates, soils, topography, Biotic factors, Land uses are interrelatedness of factors necessary to make land management through unsustainability approach. In Ethiopia the highlands have been inhabited for several centuries and agriculture constituted the main stay of the people. The farming practices and the population pressure resulted in massive soil erosion severely reducing the productive capacity of the land (Mitiku, H., 2006).

These general principles on sustainable agricultural practices focus on soil quality conditions: increase organic matter, decrease erosion, better water infiltration, more water-holding capacity, less subsoil compaction, and less leaching of agrochemicals to 


\section{Land Evaluation, Sustainable Land Management and Impacts of Climate Change in Agriculture; Ethiopia: Review}

groundwater. It can be analyze in relation to: arable land identification, crop diversification, organic matter restoration, tillage intensity, and soil input rationalization (De la Rosa, 2005).

\section{THE IMPACT OF CLIMATE CHANGE IN AGRICULTURE}

Great impacts of climate change associated with natural disasters usually lead to a massive loss in agriculture and definitely affect people"s livelihood negatively (Rwanyirizi and Rugema 2013). Global warming(due to high emission of greenhouse gases into the atmosphere) and precipitation patterns have gradually affected crop productivity and finally resulted in food insecurity (World Bank 2010a). The emissions from agriculture account for up to $30 \%$ of the global total (Garnett 2012). Ethiopia's GHG profile is dominated by emissions from the agriculture sector, followed by land-use change and forestry (LUCF), and energy sector emissions. The agricultural activities that contribute the most to the sector's emissions are enteric fermentation (52\%), manure left on pasture (37\%), and burning of the savanna (4\%).

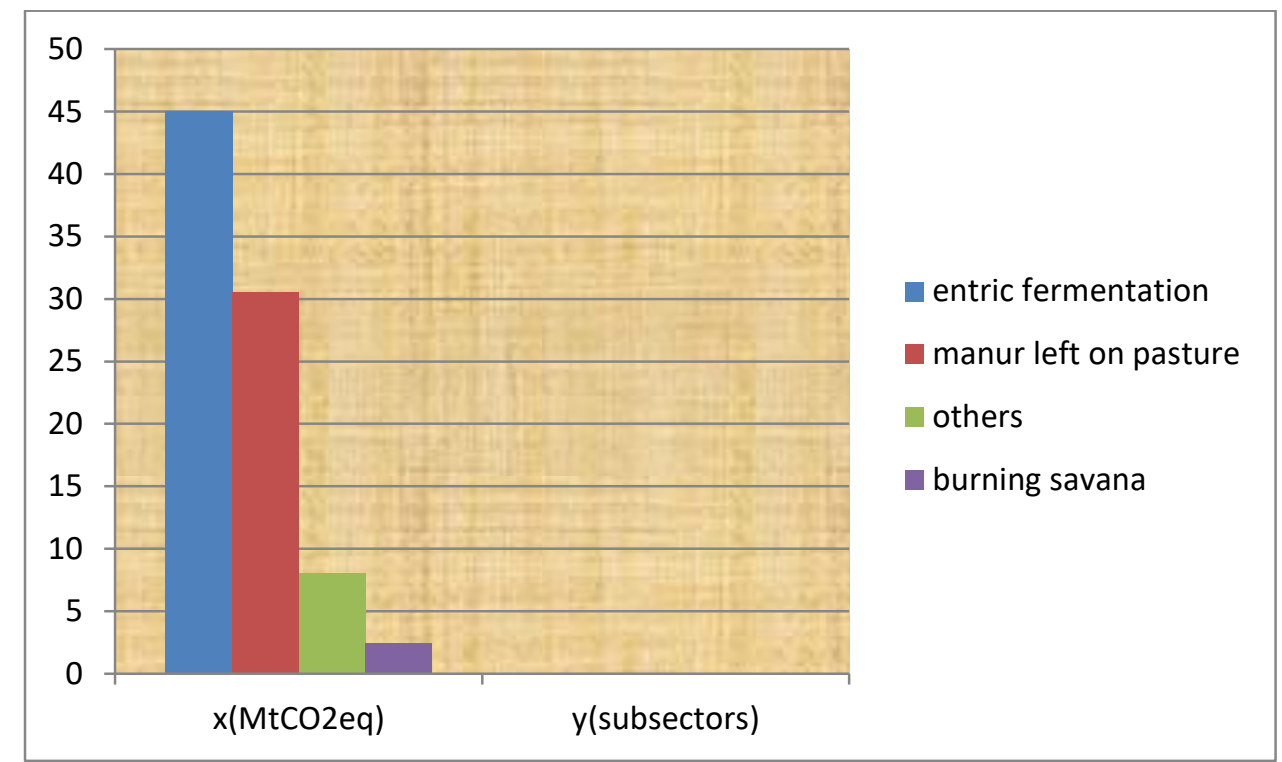

Sources: WRI CAIT 2.0, 2015; FAOSTAT, 2015

Fig 1. Ethiopia's GHG Emissions by different Agricultural subsector (2011)

Ethiopia's green house gase Emissions

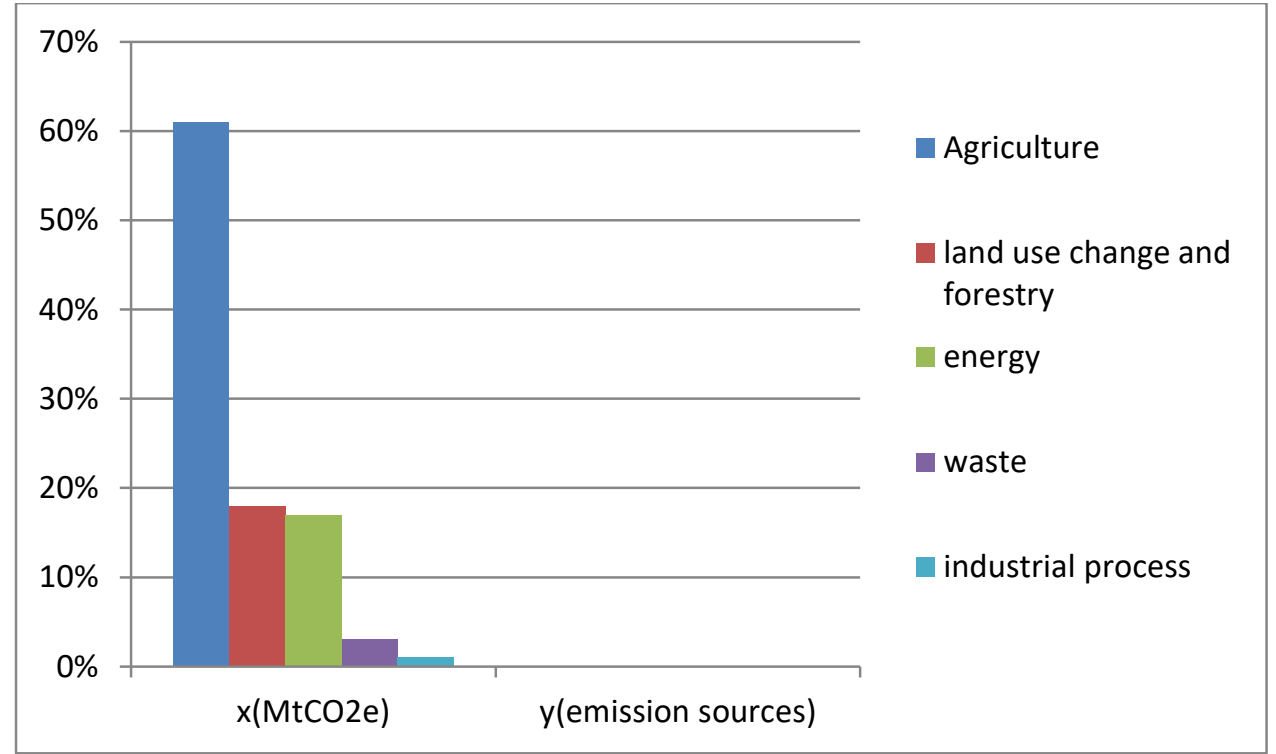

Sources: WRI CAIT 2.0, 2015; FAOSTAT, 2015

Fig 2. Total Emissions by percent (2011) 


\section{Land Evaluation, Sustainable Land Management and Impacts of Climate Change in Agriculture; Ethiopia: Review}

\subsection{Green house gas emission}

Among the greenhouse gases, carbon dioxide, nitrous oxide, methane, and fluorinated greenhouse gases are the major ones. carbon dioxide is released largely from microbial decay or burning of plantlitter and soil organic matter. $\mathrm{CH}_{4}$ is produced when organic materials decompose in oxygen-deprived from fermentative digestion by ruminant livestock, from stored manures, and from rice grown under flooded conditions. NO is generated by the microbial transformation of nitrogen in soils and manures and is often enhanced where available nitrogen exceeds plant requirements, especially under wet conditions (See 2001, Smith 2007).

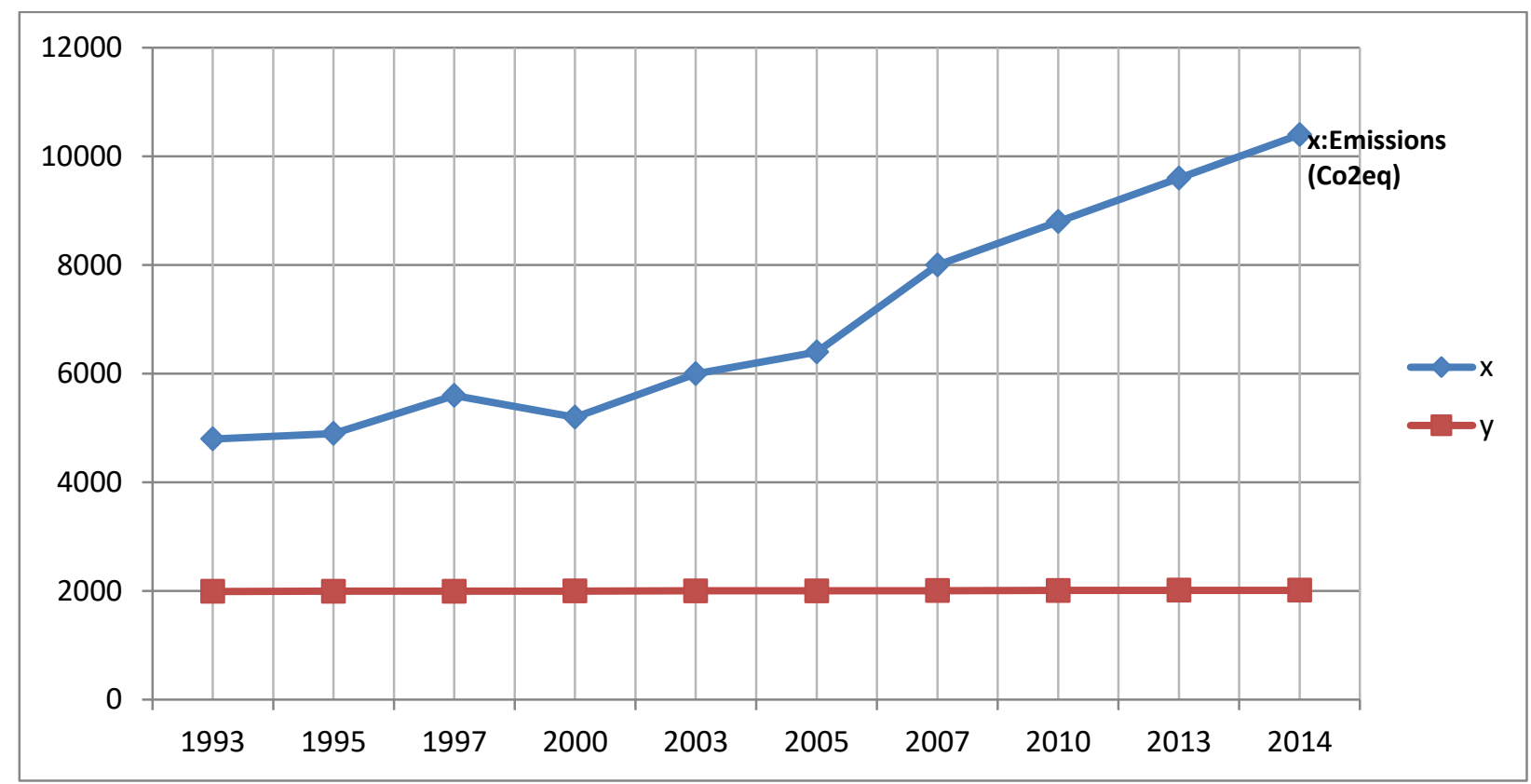

Source: FAOSTAT database FAO (2020), domain: Emissions-Agriculture.

Figure 3: Annual average of total GHG emissions from agriculture (Gg CO2eq yr-1) for Ethiopia.

\section{SUMMERY}

Land capability classification was the most widely known land evaluation (the chain leading to sustainable management of land resources) system. There is a apparent need to update framework for land evaluation to redirect current concerns related to climate change. Issues of biodiversity, global change, agro-ecosystem functions, stakeholder participation and agro-environmental monitoring need to be integrated into an updated land evaluation framework.

Many efforts have been made in Ethiopia to mitigate land degradation especially soil erosion through soil and water conservation practices. However, the strict focus on soil erosion and conservation does not necessarily lead to adequate results. Eventhogh soil and water conservation practices effective in reducing erosion, at the same time too costly and unacceptable to land users, later it will disappear and its positive effects will also be lost. This review therefore suggests to follow the broader approach of Sustainable Land Management and Soil and Water Conservation in a more holistic framework that is closer to farmers' reality.

\section{CONCLUTIONS AND THE WAY FORWARD}

In Ethiopia different research papers were proved and explain as low agricultural production, productivity and significant yield gaps. Its due to from environmental factors including climate change, soil erosion and land degradation as well as weak extension services. Therefore, improving productivity though addressing the adverse effects of climate change on agriculture is a major concern. If implemented all detail action plans of Climate Resilient Green Economy, it would have the capacity to limit greenhouse gas emissions.

In order to reach agricultural sustainability:Rainfed agriculture should not be practiced on sloping areas, in place of poor rangelands; Design a plan for increasing yield per hectare and reduce the pressure on land.

Its better to creat awareness about the policies to climate change adaptation and mitigation. Promote implementation through mainstreaming of the policies into agricultural extension, develop national climate-smart agriculture (CSA) and conservation agriculture implementation guidelines. Priority needs to be given to CSA practices that bring productivity gains, enhance resilience and reduce emissions. 


\section{Land Evaluation, Sustainable Land Management and Impacts of Climate Change in Agriculture; Ethiopia: Review}

\section{REFERENCES}

1) Campbell, B. and Hagmann, J. (2003). Rising to the challenge of poverty and environmental sustainability: Towards a conceptual and operational framework for INRM

2) Daniel M., Woldeamlak B.k \& Rattan L. (2015). conservation effects on soil quality and climate change adaptability of ethiopian watersheds

3) Deckers J., Spaargaren O., Dondeyne S. (2014). Soil Survey as a Basis for Land Evaluation, land use, land cover and soil sciences - vol. II

4) De la Rosa, D. (2005). Soil quality evaluation and monitoring based on land evaluation. Land Degradation \& Development, $16,551-559$.

5) Deressa, T., Hassan, R. M., \& Ringler, C. (2011). Perception of and adaptation to climate change by farmers in the Nile basin of Ethiopia. Journal of Agricultural Science, 149(1), 23-31.

6) Edouard S. (1972). Land evaluation for development, international institute for land reclamation and improvements

7) FAO. (1976). An overview of land evaluation and land use planning

8) FAO.(2020). Food and Agricultural Organization of the United Nations. FAOSTAT Database

9) Garnett, T. (2012). Climate Change and Agriculture: Can Market Governance Mechanisms Reduce Emissions from the Food System Fairly and Effectively?

10) Gisladottir, G., and Stocking, M. (2005). Land degradation control and its global environmental benefits. Land Degrad. doi: $10.1002 /$ ldr.687

11) Herweg, K., Slaats, J., Steiner, K. (1998). Sustainable land management - guidelines for impact monitoring.Working documents for public discussion. Centre for Development and Environment

12) Hurni, H., Meyer, K. (2002). A World Soils Agenda. Discussing International Actions for the Sustainable Use of Soils. CDE, Bern: $63 \mathrm{p}$.

13) Mitiku, H., Herweg, K., Stillhardt, B. ( 2006). Sustainable Land Management -A New Approach to Soil and Water Conservation in Ethiopia

14) [NMA] National Meteorological Agency. (2007). Climate change National Adaptation Program of Action (NAPA) of Ethiopia. Addis Ababa, Ethiopia.

15) Nyssen et. al. (2003a). Impact of Soil and Water Conservation on Catchment Hydrological Response - a Case in North Ethiopia

16) Rome (2007). land and water discussion paper, food and agriculture organization of the united nations.issn:1729-0554

17) Rwanyirizi and Rugema. (2013). "Climate Change Effects on Food Security in Rwanda: Case Study of Wetland Rice Production in Bugesera." Rwanda Journal 1 (1): 35-51.

18) See M.(2001). Greenhouse gas emissions: Global business aspects. Berlin: Springer.

19) Shiferaw, B. and Holden, S.T. (1999). Soil Erosion and Smallholders' Conservation Decisions in the Highlands of Ethiopia. World Development, 27, 739-752.

20) Smith P, et al. (2007). Agriculture in Climate Change, Mitigation,Contribution of Working Group III to the Fourth assessment Report of the Intergovernmental Panel on Climate Change.

21) Soil survey manual.(2017). Soil Science Division Staff TerrAfrica. (2009). Policy and financing for sustainable land management in sub-Saharan Africa. lesson and guide lines for action

22) Willy H. Verheye.(2009). land use and land cover - Vol. II - Land Evaluation

23) Wiesmann U, Hurni H. (2011). Research for Sustainable Development: Foundations, Experiences, and Perspectives. Perspectives of the Swiss National Centre of Competence in Research (NCCR) North-South, University of Bern, Vol. 6.

24) World Bank. (2010a). The Global Report of the Economics of Adaptation to Climate Change Study.

25) Zerga, B., \& Gebeyehu, G. (2016). Climate Change in Ethiopia Variability, Impact, Mitigation, and Adaptation. Journal of Social Science and Humanities Research, 2(4), 66-84. 